\title{
Por uma etnoarqueologia dos trançados ameríndios
}

\author{
Igor Morais Mariano Rodrigues*
}

RODRIGUES, I.M.M. Por uma etnoarqueologia dos trançados ameríndios. R. Museu Arq. Etn. 34: 87-110, 2020.

Resumo: Artefatos trançados são fundamentais em atividades básicas de transporte e processamento de alimentos para os povos ameríndios, além de ocuparem posição de destaque em suas ontologias, expressando e agenciando preceitos estéticos e visões de mundo. Eles oferecem excelentes oportunidades para estudos sobre as múltiplas relações entre humanos e o mundo material, como a variabilidade artefatual, tecnologia, corporalidade, dentre outras possibilidades, embora sejam pouco abordados em trabalhos arqueológicos e etnoarqueológicos. Esse ínfimo investimento, alicerçado, talvez, pelo baixo potencial de preservação destes materiais no registro arqueológico, acarreta na falta de conhecimento e divulgação das diversas possibilidades de pesquisa sobre os trançados, quer do ponto de vista empírico, quer do ponto de vista teórico. Trançados são perecíveis, mas persistem na vida ameríndia emaranhados em outras tecnologias. Se a Arqueologia pretende compreender a relação dos povos ameríndios e o mundo material de modo holístico, é necessário incluir também esses artefatos em sua agenda de pesquisa. Este artigo, portanto, objetiva destacar potenciais que os trançados propiciam à abordagem etnoarqueológica. Para isso, serão apontados alguns caminhos percorridos e o que está sendo desenvolvimento por meu doutorado, ainda em andamento.

Palavras-chave: Etnoarqueologia; Trançados; Tecnologias perecíveis; Povos ameríndios; Povos do rio Mapuera.

\section{Introdução}

\footnotetext{
rtefatos trançados são fundamentais em atividades básicas de transporte e processamento de alimentos para os povos ameríndios, além de ocuparem posição de destaque em suas ontologias, expressando e agenciando preceitos estéticos e visões de mundo. Eles oferecem excelentes oportunidades para compreender as múltiplas relações

* Doutorando no Programa de Pós-Graduação em Arqueologia. Museu de Arqueologia e Etnologia da Universidade de São Paulo. Laboratório de Estudos Interdisciplinares sobre Tecnologia e Território. <igor_mmrodrigues@hotmail.com>
}

entre humanos e o mundo material como variabilidade artefatual, tecnologia, estética, dentre outras, embora sejam pouco valorizados em abordagens etnoarqueológicas. $\mathrm{O}$ baixo investimento nesses estudos acarreta na falta de conhecimento e divulgação das possibilidades de pesquisa sobre trançados tanto do ponto de vista empírico quanto teórico.

A etnoarqueologia pode enriquecer nosso conhecimento sobre a materialidade e o estudo dos trançados por essa abordagem e não precisa necessariamente ser feita para gerar informações capazes de alicerçar a analogia em Arqueologia. A compreensão da materialidade por ela mesma tem sido feita em trabalhos etnoarqueológicos 
mais recentes (Lane 2015; Lyons \& Casey 2016), bem como em outras arqueologias relacionadas com práticas etnográficas (González-Ruibal 2008; Hamilakis 2011). Explorar os trançados sob uma perspectiva etnoarqueológica, portanto, é necessário para ampliar nossa compreensão sobre a constituição mútua entre humanos e coisas, ainda mais pelo fato de que essa tecnologia persiste discretamente na vida das pessoas.

Uma vez que grande parte da cultura material dos povos das terras baixas da América do Sul é composta por trançados (Ribeiro 1980), sua inclusão na agenda de pesquisa é também necessária para entender os engajamentos ameríndios no mundo material de modo holístico. Este artigo é um esforço nesse sentido, ao apontar potenciais de estudos ainda pouco explorados no Brasil. Valendo-se de produções etnoarqueológicas (Baptista da Silva 2001; Ochsenschlager 2004; Pryor \& Carr 1995; Silva 2000, 2009, 2011; Silvestre 1994; 2000; Weber 1986; Wendrich 2012) e de etnologia indigena das terras baixas sul-americanas (Barcelos-Neto 2011; Guss 1994; O’Neale 1986; Reichel-Dolmatoff 1985; Ribeiro 1980; Rivière 1992; Velthem 1998, 2003; Wilbert 1975), serão destacadas algumas possibilidades que os trançados propiciam à pesquisa. Ao final, serão apresentados exemplos pontuais de um estudo de caso etnoarqueológico com base em uma pesquisa de doutorado ainda em andamento.

\section{Cestaria e trançados: definições e como iniciar um estudo}

Cestaria, ou trançados, compõem-se de dois elementos: um rígido, ou passivo, chamado urdidura e outro ativo, a trama, que entrecruza com a urdidura formando o objeto (Ribeiro 1985). Ambos os termos, assim como tecer, derivam da tecelagem (Silva 2003: 19), por isso, diversas definições de cestaria estabelecem um limite entre essas categorias artefatuais.

A tecelagem e as redes geralmente são as categorias mais comumente usadas como contraponto nas definições de cestaria (Taveira 1982: 19). Para Mason (1904: 5), cestaria é feita com materiais relativamente mais rígidos, tecida somente com as mãos, sem o uso de máquinas, e é formada por interseção e não por nós, como no caso das malhas. Conforme Leroi-Gourhan (1971: 196-97), cestaria e tecelagem são subclasses de tecidos que não podem ser distinguidas pela forma e função do objeto nem diferenciadas pela técnica pela qual os elementos estruturantes se entrecruzam. As técnicas são indistinguíveis, porém a cestaria dispensa o tear por se valer de materiais relativamente menos flexíveis do que a tecelagem. Ainda, segundo Leroi-Gourhan (1971), considerar apenas a forma na diferenciação entre cestaria e tecelagem gera problemas, pois conceber a primeira categoria somente como objetos que forem recipientes excluirá todos os artefatos bidimensionais como as esteiras. Nesse sentido, Balfet (1952: 260) salientou que cestaria é a montagem de fibras relativamente rígidas e espessas feita à mão, resultando em superfícies contínuas e formando, geralmente, mas não exclusivamente, recipientes. Para Adovasio:

The term "basketry" applies to several different kinds of items: in addition to rigid and semi-rigid containers, matting, and bags, it embraces forms such as fish traps, hats, and cradles (1977: 1).

Mantendo a ideia de que cestaria é a técnica de produção manual que se vale de materiais relativamente mais rígidos, definições posteriores adicionaram informações mais específicas. Incluindo pormenores técnicos, para Silva (2003: 19) a cestaria é um "conjunto de práticas e possibilidades técnicas que permitem criar múltiplas formas unindo materiais" como a união de anéis de um espiral, o entrecruzamento de duas séries de elementos flexíveis, a torção de um ou dois fios envolvendo uma urdidura e a possibilidade de passar tramas sob e sobre urdiduras. Ainda, se a tecelagem requer teares e lançadeiras, na produção cesteira "basta no limite uma faca, uma agulha, um recipiente com água, e as hábeis mãos do artesão" (Silva 2003: 19). Outra definição é: 
Basketry is defined as a class of artefacts made out of vegetable fibers of limited length or with a shape which is specific to the raw material. Basketry thus defined comprises various objects such as: baskets and bags; food covers, mats, awnings and wind shields; brushes and brooms; sandals, hats and belts (Wendrich 2012: 1).

\section{Essas definições incorporaram mais} objetos e descreveram sucintamente algumas variações de técnicas produtivas, agregando ainda ferramentas auxiliares e habilidades para as mãos de quem tece. Mãos estas, aliás, que já tinham sido dotadas de "coordenação motora e a imaginação criativa do artífice” por Ribeiro (1985: 41), autora que preferiu usar o termo trançados e não cestaria por entender que é mais inclusivo, denotando a técnica de manufatura. Visto que o vocábulo cesto se estende, hodiernamente, a recipientes não trançados como cesto de lixo e cesto de compras, penso que o termo trançado seja mais adequado por, minimamente, realçar a produção feita à mão: "Se todo o cesteiro faz "cestos", nem todos os "cestos" são feitos por cesteiros. Os cestos plásticos, por exemplo, são feitos em moldes por operários fabris" (Silva 2003: 22).

Por haver muitas possibilidades de manufatura, iniciar um estudo a partir de coleções etnográficas compiladas em museus ajuda na familiarização com tamanha diversidade. Os primeiros esforços descritivos, taxonômicos e classificatórios fizeram isso, como Mason (1904) e Adovasio (1977) sobre os trançados da América do Norte, Schmidt (1904) e Ribeiro $(1980,1985)$ sobre os trançados das terras baixas sul-americanas, assim como os estudos feitos numa perspectiva global (Lehmann 1907 apud Wendrich 2012: 28; Leroi-Gourhan 1971; Balfet 1952). Os primeiros estudos etnoarqueológicos (Pryor \& Carr 1995; Silvestre 1994; Weber 1986) também recorreram às coleções etnográficas.

Trançados podem ser feitos com várias matérias-primas: talas, palhas ${ }^{1}$, fibras de folhas,

1 Palha e tala caracterizam os dois macroestilos de trançados definidos por Ribeiro (1980, 1986a). Palha corresponde ao "limbo das folhas da palmeira flabeliforme ou pinulada, extraída gramíneas, taquara, juncos ou cipós, entrecasca de árvores e caniços (O’Neale 1986; Ribeiro 1985). As técnicas manufatureiras são diversas e, no caso ameríndio, foram distinguidas basicamente em: quadricular, arqueado, sarjado, costurado, hexagonal, enlaçado, dobrado, torcido e marchetado (Ribeiro 1980, 1985, 1988). Para termos noção da enorme quantidade de possibilidades técnicas, existem em torno de 25 variantes como "enlaçado com grade”, "hexagonal oblíquo", "sarjado casa das abelhas" etc. (Fig. 1), assim como onze técnicas de partida e dez variações de arremate (Ribeiro 1985: 41-59; 74). Certamente existem variações que ainda não foram descritas e publicadas.

Sabe-se que, por estas técnicas, os ameríndios tecem cestos de transporte e armazenamento, caixas, cintos, tipoias, alças, sandálias, chapéus, peneiras, bandejas, espremedores, barcos, esteiras, abanos, armadilhas, suportes para plumária, suportes para carregar peso na cabeça, descanso para recipientes, estruturas para máscaras e demais trajes festivos, aljavas, escudos de dança, brinquedos, revestimento de empunhaduras, objetos vesicatórios etc. (Frikel 1973; O’Neale 1986; Reichel-Dolmatoff 1985; Ribeiro 1988; Velthem 2007). Trançados servem até para cozinhar, como entre os Tlingt do Alasca (LéviStrauss 1995; Wissler 1970), e para estourar pipoca, como entre os Kaingang (Kindell 1971). Existem informações de que no século XVI havia no alto-médio Amazonas ídolos trançados com estatura de gigantes (Porro 1992) e, no litoral sudeste do Brasil, cestos para moquear carne humana (Costa 2016). No século XVII os Kuna teciam pequenos cestos à prova d'água "tão cerrados que dispensavam impermeabilização" (O’Neale 1986: 334). Nota-se, portanto, que os trançados são extremamente polivalentes.

do "olho" (...) ou grelo antes de abrir-se" (Ribeiro 1986b: 319). Tala, talisca ou lâmina, é a "parte córnea do pecíolo da folha do buriti ou do colmo de uma gramínea ou marantácea, descorticada do miolo poroso e laminada para então ser utilizada no trançado. Cada tala, talisca ou lâmina assim obtida é de textura mais rígida que a palha" (Ribeiro 1986b: 320). 
A

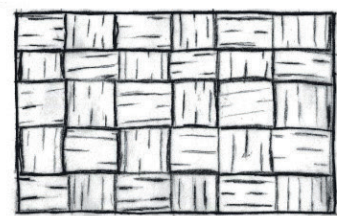

Trançado quadriculado

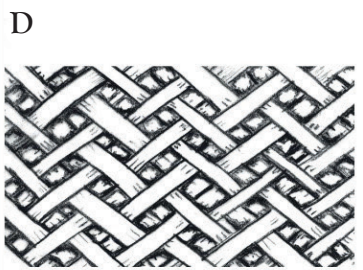

Trançado sarjado

"casa das abelhas"

G

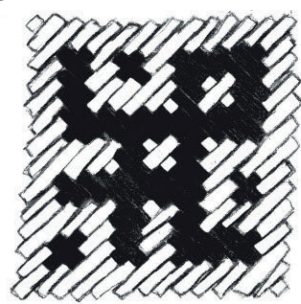

Trançado marchetado J

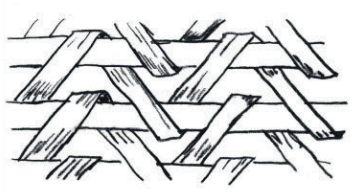

Trançado enlaçado embricado
B

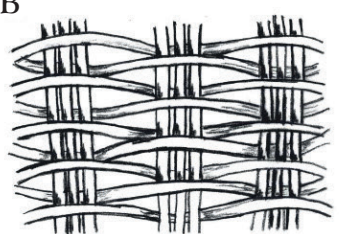

Trançado arqueado

E

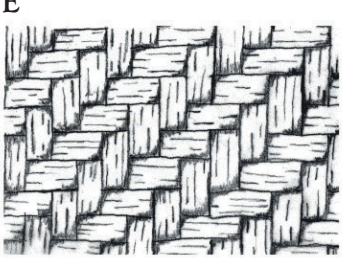

Trançado sarjado

"espinha-de-peixe"

$\mathrm{H}$

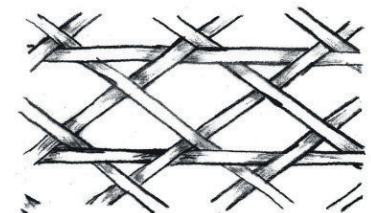

Trançado hexagonal reticular

K

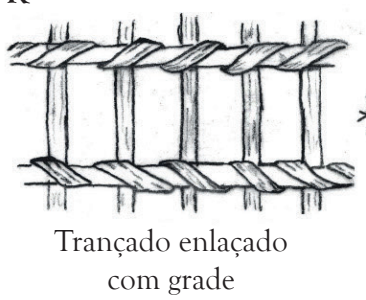

$\mathrm{C}$

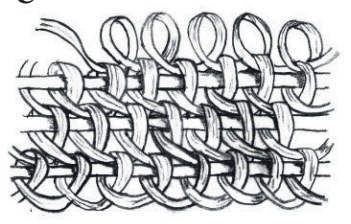

Trançado costurado com ponto de nó

$\mathrm{F}$

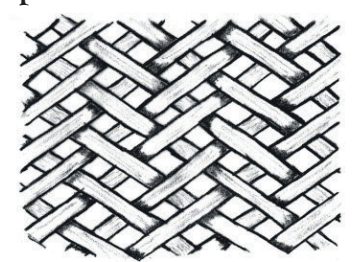

Trançado sarjado gradeado

I

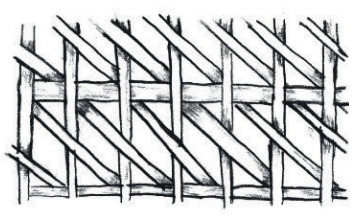

Trançado hexagonal oblíquo

L

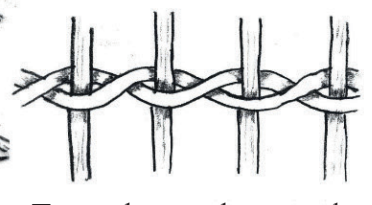

Trançado torcido vertical

Fig. 1. Exemplos de técnicas de trançados.

Fonte: Desenhos do autor. Fig. 1A, 1D e 1G: com base em objetos etnográficos. Fig. 1B, 1C, 1E, 1F, 1H-L: com base em Ribeiro (1988).

Persistentes, porém invisibilizados

A etnoarqueologia, desde seu surgimento, priorizou o estudo de populações ditas tradicionais e pré-industriais, buscando observar as relações entre humanos e materiais tais como cerâmicas, pedras e ossos, sendo, inclusive, bastante criticada por isso (Cunningham 2009;
González-Ruibal 2003, 2016; Gosselain 2016; Lane 2015). Embora tradicionais e extremamente antigas, as tecnologias perecíveis como trançados e tecelagem, com baixo potencial de preservação no registro arqueológico, raramente foram estudadas por essa abordagem.

Não obstante, quando existem boas condições de preservação, vislumbra-se quão 
presentes os trançados estavam nas vidas das pessoas. Em diversos contextos egípcios há equivalência quantitativa entre cerâmica e trançados, apesar destes geralmente estarem sub-representados no registro arqueológico (Wendrich 2012: 1). Em escavações na região centro-norte de Coahulia, México, constatou-se que artefatos de fibras perecíveis eram quatro vezes mais comuns do que instrumentos de madeira e vinte vezes mais comuns do que os de pedra, proporção não somente aplicável ao passado, mas também ao presente etnográfico dos indigenas (Adovasio et al. 2014: 332).

A tecnologia dos trançados talvez seja uma das mais antigas da humanidade, sendo precedida apenas por artefatos líticos e cordoaria (Adovasio \& Gunn 1977). Na América do Norte, há um fragmento de trançado datado diretamente em $19.600 \pm 2400 \mathrm{AP}$, além de outros encontrados em camadas datadas entre $12.800 \pm 870 \mathrm{AP}$ e $11.300 \pm 700 \mathrm{AP}$ (Adovasio et al. 2014: 336). Nas terras altas da América do Sul, existe um fragmento de trançado datado em 11.200 AP no Peru (Jolie et al. 2011) e, na Argentina, há datas entre 4.700 e 6.800 AP (Micou \& Ancibor, 1994: 214). No Brasil, ainda não foram exumados vestígios de trançados com datas muito antigas, existindo apenas sugestões de que fibras vegetais podem ter sido manipuladas entre 6 e 12 mil anos atrás (Costa 2016: 206). Em todo caso, os trançados, dentre outras tecnologias perecíveis, são vistos como cruciais para o próprio povoamento inicial, embora sejam radicalmente subvalorizados na Arqueologia (Adovasio \& Illingworth 2004).

Existem informações arqueológicas sobre trançados em praticamente todas as regiões do Brasil. Na Paraíba, fragmentos de trançados foram estudados por Costa e Moraes (2019). Costa (2016) analisou vestígios diretos em Pernambuco, Minas Gerais e Santa Catarina, além de vestígios indiretos em cerâmicas das estearias do Maranhão e da tradição Taquara do sul do Brasil. Os trançados de Pernambuco, inclusive, foram comparados com coleções etnográficas regionais, evidenciando continuidade da técnica quadriculada por mais de 1500 anos (Costa \& Lima 2016).
Em Minas Gerais, existe ainda o estudo de Dutra \& Okomura (2018) e no Mato Grosso há o trabalho de Taveira (2005). Negativos de trançados foram observados em bases de potes em Monte Alegre, Oriximiná, Santarém e na Amazônia Central (Nimuendajú 2004; Hilbert 1955) e em vestígios de fauna no sítio Hatahara (Py-Daniel 2010). No Planalto das Guianas, há negativos em cerâmicas das fases Rupununi e Tarumã (Evans \& Meggers 1960; Boomert 1981) e em Roraima, Mentz Ribeiro (2000) encontrou trançados em sepultamentos sob abrigo.

Nas Américas, a tecnologia dos trançados é tão antiga quanto a tecnologia lítica, mas, diferente desta e da cerâmica que estão inexoravelmente deixando de ser produzidas, trançados seguem povoando a vida dos ameríndios, convivendo com panelas de alumínio, recipientes plásticos, motosserras, geradores de energia, computadores, smartphones etc. Nesta perspectiva, trançados são mais duráveis na vida ameríndia do que artefatos de pedras e de barro. Existem casos em que não há alternativas além do trançado, como o tipiti que não possui equivalente industrial para substituí-lo por ser muito especializado (Rivière 1992: 147).

Entretanto, isso não explica a persistência dos trançados que podem perfeitamente ser substituídos, como abanos, peneiras, cestos cargueiros, entre outros. Para Rivière (1992), os trançados ameríndios possuem valores estéticos e culturais específicos que superam seu valor funcional, o que possivelmente contribui para sua manutenção na vida dessas populações.

Se as cerâmicas resistem aos intemperismos e permanecem no registro arqueológico, no uso cotidiano elas são relativamente frágeis e preci-sam ser manipuladas com cautela, fazendo-nos mais conscientes de sua presença (Silva 2003). Já os trançados não precisam dos mesmos cuidados. Persistentes, eles também são mais resistentes e isso contribui para que passem despercebidos em nossas vidas e tenhamos com eles uma relação um tanto quanto ambígua: "Queremos os cestos conosco, mas não lhe ligamos nenhuma. De tão familiares, eles tornaram-se invisiveis" (Silva 2003: 24). Como reflexo, trançados e demais tecnologias perecíveis são mais intelectualmente 
invisibilizados na Arqueologia do que invisíveis de fato (Stone 2011).

\section{Etnoarqueologia e trançados}

Existem poucas pesquisas etnoarqueológicas sobre trançados. David \& Kramer (2001), numa das principais obras sobre etnoarqueologia, mencionam apenas o estudo de Silvestre (1994) nas Filipinas. Não obstante, há os estudos de Weber (1986) e Pryor \& Carr (1995), respectivamente sobre os trançados de povos do Alasca e Califórnia, além das pesquisas de Wendrich (2012) no Egito e Ochsenschlager (2004) no Iraque. No Brasil, Silva estudou os trançados Xikrin $(2000,2011)$ e Asurini (2009) enquanto Batista da Silva (2001) abrangeu a cestaria dos Kaingang e MbyáGuarani em sua tese sobre grafismos.

No periódico Ethnoarchaeology, não existe sequer um único artigo devotado aos trançados. Em dez anos de sua existência (entre 2009 até a primeira publicação de 2019), foram encontradas apenas referências pontuais aos trançados em sete artigos (Al-Houdalieh 2010; Casey \& Burruss 2010; Daniel \& Beldados2018; Hirshman \& Stawski 2013; Jones et al. 2012; Lyons 2009; Wilmsen et al. 2016) que, de modo geral, abordaram unidades residenciais, atividades domésticas, de processamento e transporte de vegetais e minerais. Em coletâneas recentes (Biagetti \& Lugli 2016; Marciniak \& Yalman 2013) que envolveram estudos etnoarqueológicos de pesquisadores da China, Turquia, Mongólia, Rússia, Alemanha, Bulgária, Holanda, Itália, Espanha, França, Suíça, Suécia, Polônia, Romênia, Sérvia, Inglaterra, Canadá e Estados Unidos da América, pouco foi encontrado. Os textos de Wendrich (2013), Gallay (2016) e Piqué et al. (2016), apenas mencionam a existência de trançados.

Outras referências pontuais foram identificadas em trabalhos completos publicados em livros. A obra de Politis (2007) sobre os Nukak da Amazônia, informa que mulheres especialistas tecem cestos cargueiros paneiriformes com cipó-titica, peneiras circulares de arumã com malha hexagonal e braceletes com fibra de tucum. Existem ainda os cestos búrup, feitos com folhas de palmeiras. A versatilidade dos trançados é exemplificada no uso das paredes do cesto cargueiro para peneirar (Politis 2007: fig. 7.15) e no uso das peneiras como tampa dos cestos cargueiros durante os constantes deslocamentos dos Nukak. Já nas Ilhas Fiji, a pesquisa de Jones (2009) entre os Lau mencionou esteiras, abanos e cestos presentes em atividades domésticas femininas, servindo para transporte e armazenamento de alimentos ou lenha, além do auxílio na coleta de peixes. Interessante é a referência aos cestos nas relações e denominações hierárquicas deste povo, que chamam o irmão mais novo de "basket carrier", já que o cesto cargueiro costuma ficar na extremidade inferior da casa (Jones 2009: 29).

Essas referências, ainda que sucintas, indicam minimamente a presença dos trançados em diversas facetas das vidas de inúmeros povos. Ademais, elas realçam um potencial de pesquisa que fica mais evidente nos estudos etnoarqueológicos específicos sobre os trançados.

De modo geral, os estudos existentes contribuíram com discussões e desenvolvimento de modelos gerais que pudessem ajudar nas inferências arqueológicas. Enquanto alguns puderam comparar os trançados do presente etnográfico e do passado arqueológico, outros abrangeram coleções etnográficas. Já a cosmologia nativa em relação aos trançados foi explorada, sobretudo, nas pesquisas brasileiras. Apresenta-se a seguir um panorama global e brasileiro de pesquisas etnoarqueológicas sobre trançados.

\section{Panorama global}

As etnoarqueologias que tiveram a oportunidade de comparar trançados atuais com arqueológicos de uma mesma região demonstraram que, apesar de versáteis, eles podem ser uma categoria extremamente conservadora ao longo do tempo. Tanto no caso iraquiano (Ochsenschlager 2004) quanto no egípcio (Wendrich 2012), observou-se que muitos trançados continuam sendo feitos até os dias atuais, mesmo com severas 
mudanças históricas desde os tempos da Antiga Mesopotâmia e do Antigo Egito, respectivamente. A pesquisa de Ochsenschlager (2004), realizada entre 1968 e 1990 nos momentos em que o autor esteve de folga de suas escavações no sítio arqueológico al-Hiba, enfatizou os trançados apenas em um capítulo de seu livro. $\mathrm{O}$ autor basicamente recorreu aos trançados etnográficos para compreender como foram feitos os trançados arqueológicos. Já o estudo de Wendrich (2012), exclusivo sobre a cestaria, constatou que há mais diferenças entre a cestaria atual do Médio Egito e da Núbia do que entre as cestarias antigas e modernas de cada uma dessas regiões, indicando que as tradições regionais são mais fortes e persistentes ao longo do tempo.

Outro potencial da abordagem etnoarqueológica refere-se à dinâmica produtiva. Ao refletir sobre as supracitadas noções de urdidura e trama, Wendrich (2012) observou que, dependendo da técnica, as urdiduras podem ficar ativas na estruturação inicial de uma peça até as tramas entrarem em cena. Isto é, o que é ativo pode ser passivo num determinado momento e vice-versa, permitindo-nos flexibilizar nossa visão acerca dos elementos estruturais básicos de um trançado qualquer. Considerando o tempo da produção de um objeto e as especificidades e habilidades tecelãs individuais, a autora demonstrou que trançar envolve todo o corpo como instrumento (ênfase minha), sendo imprescindível o posicionamento adequado dos pés, o uso correto e ritmado das mãos, o uso do peso corporal e até os dentes. Sua pesquisa evidenciou que trançar é uma técnica corporal no sentido cabal de Mauss (2003).

Existem também etnoarqueologias que recorreram às coleções etnográficas. Comparando atributos dos cestos como morfologia, profundidade, diâmetro de boca, técnicas produtivas, ornamentação e função com a etnoclassificação disponível, Weber (1986) buscou elaborar um método geral de classificação que pudesse ser significativo tanto para a Arqueologia quanto para os produtores. Esse autor ainda fez uma pequena comparação entre os trançados dos Tlingit do norte, Tlingit do sul, dos Nootkan, Haida, Eskimo e Aleuta, identificando cinco estilos regionais, por mais que alguns tenham mais semelhanças entre si do que outros. Verificou-se que o estilo do trançado entretorcido dos Tlingt e dos Haida são diferentes no que tange aos padrões gráficos e, sutilmente, na direção do entretorcimento. Enquanto os primeiros tecem com o cesto de boca para cima, os segundos tecem com o cesto emborcado, resultando, por exemplo, que o entretorcimento Tlingt se dá no sentido anti-horário e o Haida no sentido horário, quando observados numa mesma posição. Weber (1986) demonstrou a importância de considerar o estilo de trançar em vez de apenas analisar o produto final.

Esse potencial em deslindar fronteiras estilísticas nos modos de tecer foi aprofundado em Pryor \& Carr (1995) ao envolver análises em escala individual e regional, comparando as produções entre vários povos Pomo da Califórnia e dos povos adjacentes. Exemplares de coleções etnográficas foram usados em diálogos com as produtoras de cesto para tratar de questões sobre estilos e suas fronteias, destacando o potencial dos trançados para abordar os imbricados processos individuais, familiares e comunitários nas manufaturas. Pryor \& Carr (1995) demonstraram a importância de se considerar as técnicas, morfologia e padrões gráficos, porquanto eles podem estar ligados a fatores de interação e distância entre pessoas e comunidades que, por sua vez, apresentam conexão com a geografia, sistemas de aprendizado, relações de parentesco, amizade e casamentos.

Utilizando também trançados de coleções etnográficas, Silvestre $(1994,2000)$ abordou a produção, consumo e circulação da cestaria Kalinga, nas Filipinas, para compreender o advento da especialização produtiva em sociedades de pequena escala que, segundo ele, é causado pela intensificação econômica. Apesar dessa visão pragmática que pode se enquadrar perfeitamente no que Sahlins (2007) denominou de "antropologia da necessidade", Silvestre informou que os próprios Kalinga distinguem os homens especialistas (denominados magla-laga), que dominam mais técnicas e fazem formas mais difíceis, dos não especialistas. 
Os magla-laga se diferenciam entre si pelo modo de construção das bordas, largura das tramas, emendas, proporções dos cestos e preferências na produção de grafismos geométricos, sendo o arremate a característica idiossincrática mais conservadora (Silvestre 1994, 2000). Por fim, ao comparar seu trabalho com os estudos sobre a cerâmica dos Kalinga, Silvestre (2000) notou que as mesmas variáveis observadas nos modelos de diferenciação desta categoria artefatual, como frequência, sazonalidade, variabilidade de matérias primas, entre outras, são perfeitamente aplicáveis aos trançados.

\section{Panorama brasileiro}

Os trabalhos feitos no Brasil exploraram aspectos cosmológicos e do pensamento nativo acerca dos trançados. Se valendo de coleções etnográficas Kaingang, Baptista da Silva (2001: 15) estudou os grafismos deste povo para compreender "sua arte, sua estruturação social e sua mitocosmologia" aspirando desenvolver um modelo de compreensão das "sociedades Proto-Jê meridionais". Como contraponto, o autor também analisou coleções do povo Mbyá-Guarani. Embora não tenham sido exclusivos em sua análise que, no caso Kaingang também envolveu tecidos, armas e pinturas corporais, nota-se que os trançados tiveram papel de destaque, pois são referências visuais claras da alteridade Kaingang perante outros povos e a sociedade nacional envolvente; trançados de recobrimento são observados em outros objetos como arcos, bengalas, garrafas, tiaras, flautas, entre outros; logo na manufatura, os trançados revelam grafismos que podem corresponder às marcas das duas metades da organização social Kaingang, evidenciando assim sua cosmologia dualista (Baptista da Silva 2001: 167-176).

Já no caso Mbyá-Guarani, também estudado por Baptista da Silva (2001), somente os trançados foram analisados, sendo possível compreender que, para este povo, existem padrões sagrados, originados pelo criador Ñanderu, e os inventados pelas próprias pessoas. A origem dos primeiros vincula-se à própria origem dos cestos (Baptista da Silva 2001: 227), correspondendo a padrões geométricos cujos motivos iconográficos se referem às partes anatômicas de seres primevos, como o desenho da cobra cascavel, da mandíbula do peixe e assim por diante. Este trabalho propôs que os grafismos Kaingang e Mbyá-Guarani possuem estreitos vínculos com as cosmologias destes povos. Enquanto os primeiros manifestam temas da organização social dual Kaingang, os segundos tratam de aspectos do domínio natural e sobrenatural Mbyá-Guarani.

Trançados de povos falantes de línguas Jê e Tupi-Guarani também foram abordados por Silva $(2000,2009,2011)$ que, ao pesquisar a tecnologia e variabilidade artefatual, apresentou descrições sobre as sequências de manufatura, abordou aspectos sociais e cosmológicos ligados à cestaria, além de tratar dos processos de ensinoaprendizagem responsáveis pelas produções. Em linhas gerais, estes processos vinculam-se ao parentesco e unidade doméstica, sendo o conhecimento transmitido dos mais velhos aos mais jovens, muito embora preferências individuais possam se manifestar sobretudo nos grafismos (Silva 2000, 2009, 2011). Outrossim, a autora também se valeu dos conceitos binfordianos de tecnologia expediente e de curadoria para distinguir, grosso modo, os cestos feitos de forma mais rápida, sem preparo refinado de matéria prima e geralmente descartados logo após o uso, e os produzidos de forma mais elaborada e mais duráveis.

No caso Xikrin, Silva $(2000,2011)$ demonstrou que esses conceitos apresentam paralelos com o pensamento nativo, já que eles entendem como cestos não verdadeiros os categorizados por ela de expedientes e cesto verdadeiro o categorizado como de curadoria. Estes são os únicos concebidos enquanto corpos. O cargueiro ko-kumrené composto de boca, garganta, costas e nádegas, e sua decoração deve seguir as mesmas prerrogativas da decoração corporal humana, apresentando pintura facial perto de seus olhos e também recebendo enfeite frontal (Silva 2000: 105). Existem cestos de curadoria que apresentam grafismos específicos entendidos como krukràdjà, vocábulo indicativo 
de herança ou propriedade de indivíduos específicos que, por sua vez, possibilita identificar a pessoa que o produziu (Silva 2011: 181).

Para os Xikrin, a manipulação de determinadas matérias e produção de artefatos fora da categoria de idade adequada pode provocar doenças, como é o caso do cesto kà kumrenx, tecido apenas por homens com filhos, na medida em que já possuem corpos fortes (Silva 2000, 2011). Por outro lado, há casos de relação positiva entre determinadas substâncias dos vegetais e os humanos, como o uso da tipoia trançada com fibra de buriti, que propicia à criança recém-nascida "um crescimento rápido e forte, ficando a mesma alta e esguia como a própria palmeira" (Silva 2000: 128).

$\mathrm{Na}$ pesquisa com os Asurini, Silva (2009) observou que a variabilidade formal dos trançados resulta das escolhas comunitárias como um todo, assim como se vincula às preferências individuais, envolvendo fatores de ordem prática e simbólica. No que tange aos grafismos, eles foram copiados de um ser sobrenatural e rementem, na maioria os casos, a outros seres, tais como peixes ou teias de aranha. A autora observou que a performance dos trançados também é considerada nas escolhas produtivas, como o tamanho proporcional dos cestos cargueiros ao seu usuário, a seleção de matérias resistentes para estes cestos e a produção de estojiformes bem fechados para proteger os itens guardados. Em relação à variabilidade quantitativa, Silva (2009: 27-30) observou que a frequência do uso dos trançados pode aumentar sua quantidade; que a comercialização e substituição por bens industrializados podem, respectivamente, aumentar ou diminuir a quantidade; que existem mais trançados em casas onde residem homens velhos que sabem fazê-lo. Por fim, a autora argumentou que os trançados, além de funcionalmente importantes na vida dos Asurini, reafirmam a identidade cultural deste povo, tal como reforçam suas relações sociais e expressam conhecimentos técnicos e cosmológicos.
As etnoarqueologias dos trançados: aspectos gerais e particulares

Todas as pesquisas sintetizadas acima realçaram a complexidade e amplitude de diversos fatores envolvidos na produção dos trançados, como seleção de materiais e os usos pretendidos, a relação ensino-aprendizagem, as trajetórias individuais de quem produz e como isso influencia o desenvolvimento dos estilos individuais e comunitários. Outrossim, a tecnologia dos trançados deve considerar o processo de manufatura, e não somente o resultado. Quer seja entre os Pomo californianos, quer seja entre os Kalinga filipinos ou entre os Xikrin amazônicos, fica patente que as preferências pessoais se manifestam notadamente nos grafismos.

Existem ainda dados particulares de povos específicos que escapam das propostas de construção de modelos gerais. Por exemplo, sabe-se que os Kalinga penduram pequenos cestos fora de suas casas no intuito de espantar maus espíritos e, antigamente, cestos específicos participavam nos rituais de caça de cabeças dos inimigos (Silvestre 2000: 102-103). Há também relações afetivas das pessoas Kalinga com seus trançados, como exemplificado na recusa das pessoas em vender cestos velhos por eles possuírem "stories to tell" (Silvestre 1994: 204). A indicação de que para os Mbyá-Guarani a origem dos grafismos está entrelaçada com a dos cestos (Baptista da Silva, 2001) e as abordagens sobre a noção da pessoa, prescrições, corporalidade e relações consubstanciais entre humanos e vegetais (Silva 2000) são outros exemplos. Entre os árabes dos pântanos do sul do Iraque, muitas das gramíneas usadas nos cestos também servem de alimentos e tamanha é a importância delas na vida das pessoas que são discriminadas e nomeadas quatro fases de seu crescimento, conforme suas possibilidades de uso (Ochsenschlager 2004: 130). Isso demonstra que relações mais profundas entre humanos e vegetais não são exclusivas de contextos ameríndios. 
De acordo com o exposto nas pesquisas brasileiras, me parece que algumas particularidades da concepção dos trançados são mais semelhantes entre os povos aparentados pela língua. Por exemplo, os falantes de língua Jê, como Kaingang e Kayapó-Xikrin, pensam seus trançados de um ponto de vista cosmológico marcado pela dualidade, centrado na organização social e nos próprios humanos, enquanto os Mbyá-Guarani e Asurini, falantes de línguas Tupi, os conectam aos seres naturais e sobrenaturais dos primeiros tempos. Contrapondo os Xikrin aos Wayana, povo falante de língua Karib e estudado por Velthem (1998, 2003), Silva (2000: 116) destacou que apesar de ambos os povos pensarem seus trançados por meio da corporalidade, para os primeiros, os modelos são seus próprios corpos, enquanto os segundos relacionam com os corpos de seres arquetípicos dos tempos primevos.

Além das questões apresentadas por este artigo, existem outras que ainda podem ser tratadas no estudo dos trançados ameríndios das terras baixas da América do Sul sob uma perspectiva etnoarqueológica. Isso fica mais evidente quando se considera diversos aspectos dos trançados na vida desses povos.

\section{Os trançados na vida dos povos ameríndios: aspectos gerais}

Trançados estão onipresentes em várias esferas da vida dos povos ameríndios e são extremamente importantes, já que atuam em afazeres cotidianos, rituais e festivos, sendo também produzidos para venda.

Além de quantitativamente significativos, eles estão imbricados com a noção de pessoa, cosmologia, corporalidade, ontologia e relações sociais e estéticas, dimensões fulcrais em pesquisas sobre tecnologia. Abordar os trançados na vida dessas pessoas, portanto, requer concatenar tais dimensões.

Entre os povos campestres, os trançados representam a maior parte da cultura material e, entre os povos que têm na mandioca brava a base de sua alimentação, os utensílios mais importantes para processar esse tubérculo são trançados (Ribeiro 1980: 4-5).

Neste processamento, os trançados são ligeiramente mais numerosos em relação aos itens de madeira, cerâmica, pedra e osso/concha (Brochado 1977)². Além disso, quase todas as atividades materiais que uma pessoa Yekuana, por exemplo, precisa realizar envolve trançados (Guss 1994) e o mesmo foi observado entre os Warao (Wilbert 1975). Entre os Tenetehara, 40\% dos objetos técnicos são trançados (Wagley \& Galvão 1961 apud Ribeiro 1980: 138) e entre os povos do Alto Rio Negro eles correspondem a 51\% (Ribeiro 1980:135). Tendo em vista a expressividade dos itens derivados de fibras vegetais entre populações indígenas, Ribeiro (1980) denominou-os de "civilização da palha".

Considerando apenas as palmeiras, donde provêm palhas e algumas talas usadas nos trançados, há cerca de vinte gêneros empregados para os mais diversos fins, desde frutos comestiveis, vinho, palmito, polvilho, óleo e sal, até usos na cobertura de habitações, produção de cordões, cordas e fios, produção de ornamentos, de artefatos em madeira e, claro, os trançados (Lévi-Strauss 1986). Em termos de espécies, sabe-se que ao menos 194 são usadas somente no noroeste da América do Sul (Smith 2015: 1). Conforme Fuerst (1970), no século XVIII foi observado que os povos habitantes do delta do Orinoco consideravam o buriti como a árvore da vida e sua própria pesquisa com os Xikrin o fez considerar este povo "Une civilisation du palmier", dada a importância das palmeiras. Para os Krahô, "o buriti compõe o universo ritual como alimento e matériaprima para a confecção dos artefatos e das toras" (Castro 1994: 16). Os cestos búrup, dos Nukak, tecidos rapidamente com folhas de palmeiras, são os artefatos mais abundantes,

2 Resumidamente, trançados são usados para: transporte, imersão das raízes em água, exposição ao sol, armazenamento, espremer o suco venenoso, peneirar e coar. Artefatos de madeira são usados para: moquear e defumar, pilar, raspar e ralar, recolher e armazenar, torrar. Cerâmicas servem para: lavar, decantar, assar, ferver e fermentar. Pedras são usadas para: raspar, ralar. Osso e concha: raspar (Brochado 1977: 41-42). Apesar do autor não mencionar, ressalto que muitos dos abanos usados para avivar o fogo são trançados. 
podendo ser produzidos diariamente cerca de seis deles (Politis 2007). Nesse sentido, não seria espantoso observar casos nos quais as pessoas passam boa parte de seu tempo se relacionando de alguma forma com os trançados, como os Ye'kuana que "devote more time to basket manufacture than to all other handicraft activities combined" (Hames \& Hames 1976: 25).

Haja vista a importância do processo de tecer, como exposto na seção anterior, destacase que trançar é uma nobre arte que se presta a inúmeros usos e que alcança uma perfeição inigualável entre os ameríndios (Lévi-Strauss 1995) ao ponto de ter sido afirmado que, notadamente entre os povos das Guianas, a mais "alta proficiência técnica e virtuosismo artístico" se encontra nos trançados (Gillin 1948: 838, tradução minha). Até Boas (2014: 97-99), no início de um capítulo destinado a tratar o simbolismo da "arte primitiva”, recorreu à cestaria da, até então, Guiana Britânica, considerando seu destaque. A habilidade de trançar dos ameríndios amazônicos, por vezes, é reputadamente uma qualidade moral e o status de pessoas talentosas pode até se assemelhar ao dos xamãs (Rivière 1992). A própria manufatura é concebida enquanto diálogo metafísico articulado com as mãos, fazendo da habilidade cesteira um índice análogo para outras qualidades intangiveis e que também exemplifica o desenvolvimento simultâneo da competência técnica e ritual de uma pessoa (Guss 1994: 96).

A tecnologia do trançado ocupa posição de destaque no pensamento e na cosmologia ameríndia (Velthem 2003; Barcelos-Neto 2011). Remetendo ao sobrenatural, trançados também representam um estado de equilíbrio entre natureza e cultura, correspondendo a objetos particularmente sensíveis, pois são provenientes da natureza e a ela retornam numa passagem carregada de significações e interdições (Lévi-Strauss 1995). Segundo Reichel-Dolmatoff (1985: 25): "The weaving of basketry is a Desana metaphor for the life process, for sex, kinship, and food". Para Guss (1994: 18), cestos são como um prisma que reflete todo o universo Ye'kuana. Além disso, trançados podem ser entendidos como materialização da oralidade mítica, uma vez que podem ser "imagens conceituais" ${ }^{3}$ dos mitos, como o tipiti que carrega em si um pouco da "serpentinidade" por possuir a capacidade de constrição típica das serpentes (Velthem, 2009: 214-217).

Trançados são tidos como boa metáfora para o tema da transformação corporal (Barcelos-Neto 2011). Fazendo uma rápida digressão, corpos apresentam uma complexa linguagem simbólica em torno de sua fabricação, pois é através deles que se constrói a noção de pessoa e que se elaboram as cosmologias ameríndias (Seeger et al. 1979). Inclusive, a noção de que corpos servem como modelo de diferenciação possibilitou a formulação do "perspectivismo ameríndio" (Viveiros de Castro 2002, 2015). Disso decorre que existem diversos exemplos que evidenciam a profunda ligação entre trançados e corporalidade, desde mitos ao modo como os indígenas concebem esta categoria artefatual.

Segundo os Arekuna, a origem do timbó se vincula ao sangue e partes decompostas de um cadáver que caíram sobre o solo após escorrerem de um cesto cargueiro (Lévi-Strauss 2004: 302). Conforme os Tiriyó, os humanos foram criados a partir de um trançado que em seguida teve alma adicionada, por isso seus desenhos são similares aos dos corpos humanos, além de outras versões em que os personagens trançam para si roupas de onça e saem para caçar (Rivière 1992: 155-158). Um xamã Desana pode perfeitamente transformar um tipiti numa serpente para devorar uma vítima (Reichel-Dolmatoff 1985: 27) e o que impede o tipiti de atacar as mulheres Wayana é o fato de não possuir cabeça nem rabo (Velthem 2001, 2003, 2009).

Para diversos povos, como os Tiriyó (Frikel 1973), Ye'kuana (Guss 1994), Wayana (Velthem 2001, 2003), Warao (Wilbert 1975), Kaingang (Kindell 1971), Karajá (Taveira 1982), Xikrin (Silva 2000) e Desana (Reichel-Dolmatoff 1985), os trançados apresentam partes de corpos,

3 Segundo Velthem (2009: 214), a noção de imagem conceitual implica em que "o elemento representado está mais particularmente relacionado com o conhecimento que se tem a seu respeito do que com sua visualização mesma”. 
podendo ser concebidos enquanto tal, ou melhor, como "corpos despedaçados", para usar a expressão de Velthem (2003:124).

Braços, costelas e costas do cesto cargueiro Karajá, do tipo jamaxim, "coincidem, quando em uso, com as partes do corpo de quem as carrega" (Taveira 1982: 101). Na perspectiva ameríndia, artefatos "apontam necessariamente para um sujeito” (Viveiros de Castro, 2002: 361) e sua agência está diretamente relacionada a sua corporalidade (Vethem 2009: 230).

Eles são corpos assim como corpos são artefatos fabricados pela sociedade (Velthem 2003; Lagrou 2009), destacando a necessidade de se levar a sério uma ontologia da tecnologia em contextos ameríndios, "uma tecnologia através da qual as pessoas e as coisas se constituam mutuamente" (González-Ruibal et al. 2013: 130).

Trançados são corpos que atuam na construção estética e auxiliam na intermediação da sociedade sobre os corpos humanos, contribuindo para determinar gênero e faixa etária dos indivíduos, como é o caso das placas vesicatórias, alguns cintos, tipoias e suportes para plumária (Velthem 2007; 2009). Tecnicamente, as placas usadas para colocar formigas e vespas que causam vesículas na pele contribuem para construir o corpo das pessoas. Entre os Wayana: "As formigas conferem saúde e capacidade reprodutiva ao jovem, as vespas, as habilidades requeridas para o manejo do arco e flecha, com os quais exercerá atividades predatórias" (Velthem 2009: 224).

Outro exemplo é o cesto kaipó dos Krahô, que, além de marcar a aliança social entre marido e mulher, pode ser usado para guardar cocos de babaçu, cujo óleo é importante para manter apropriadamente os cabelos (Castro 1994). Deste modo, o kaipó está inter-relacionado com a tecnologia da fabricação da pessoa krahô. Polivalentes, trançados são mediadores em diversas situações, quer na vida, quer na morte, servindo para reforçar valores e definir papéis e relações sociais (Velthem 2001).

No pensamento do povo Aché existe uma oposição entre arco e cesto que marca os papeis masculinos e femininos, expressando as diferenças socioeconômicas entre os homens, caçadores da floresta, e as mulheres, produtoras de cestos, responsáveis pela vida nos acampamentos e por carregar as tralhas em suas constantes mudanças (Clastres 1990).

Estes artefatos são "o meio, o signo e o resumo de dois "estilos" de existência", sendo o cesto o símbolo do transporte e do que é ser mulher entre este povo (Clastres 1990: 74-75). Justamente por estarem relacionados às roças, aos alimentos e à vida doméstica, além de narrativas que contam que eles se transformaram em mulher e vice-versa, cestos cargueiros costumam ser tidos como a "metonímia da mulher" (Velthem \&

Robert 2012: 8). Todavia, nem sempre os cestos cargueiros são feitos por elas, como no caso Aché. Entre os Mundurukú, o cesto cargueiro itiú é feito por homens que, após aplicarem grafismos informativos do clã patrilinear, dão às suas filhas e esposas (Velthem 1992: 89). O cesto kax, dos Mebêngôkre, é elaborado pelos homens, apesar do uso exclusivo ser das mulheres (Velthem \& Robert 2012: 20). No norte amazônico, com exceção dos povos Maku e Yanomami, a cestaria basicamente é uma atividade masculina (Velthem 2007: 125).

Fazer cestaria de arumã bem-feita atesta que um jovem Baniwa se tornou adulto (Ricardo 2000). Se tornar uma pessoa que sabe fazer objetos através de técnicas específicas é se metamorfosear para os Wayana, e o domínio da produção do tipiti, um dos mais difíceis de ser feito, indica que um rapaz está apto para se casar (Velthem 1998). Não obstante, existem casos em que jovens só passam a se preocupar em aprender os trançados básicos quando chega a responsabilidade de sustentar sua casa, como entre os Karajá (Taveira 1982: 163).

Para os Wayana, a cestaria assinala a complementaridade entre o fazer, atividade masculina, e o usar, atividade feminina, embora alguns trançados sejam usados por homens (Velthem 2007: 136). Essa diferença marca, inclusive, os modos de olhar e se referenciar aos trançados, pois as mulheres os nomeiam conforme o uso, enquanto os homens nomeiam conforme a matéria-prima utilizada ou por seus padrões gráficos (Velthem 1998, 2001).

A relação entre trançados e grafismos é profunda. Dada a versatilidade e onipresença 
dos trançados na vida dos ameríndios, pode-se até pensar que eles sejam um dos principais meios pelos quais os grafismos são exibidos e vistos no cotidiano desses povos. Afinal, trançar é fazer grafismos.

\section{A imanência dos grafismos nos trançados}

A pesquisa sobre trançados ameríndios possibilita desconstruir dicotomias entre função/decoração e entre arte/tecnologia. Isso não é somente desejável, como é central nos estudos sobre técnicas em sociedades não ocidentais (Lemonnier 1992; Ingold 2001). Para os Pomo californianos, os espíritos dos cestos vivem na decoração trançada: "são o povo da decoração”, logo, o padrão deve incluir uma "porta" rompendo a continuidade do motivo que permitirá o espírito sair do cesto quando morrer (Lévi-Strauss 1995: 118). Trançados e padrões gráficos estão intimamente conectados, pois durante as ações produtoras dos cestos, trançar não se dissocia do fazer grafismo. Sua pele e corpo resultam da mesma ação sobre a matéria, deste modo um trançado é concomitantemente um ser/ter decoração (Barcelos-Neto 2011; Velthem 1998).

Em um dos primeiros estudos sobre trançados ameríndios, foi demonstrado que trançar invariavelmente produz desenhos. Segundo Schmidt (1904: 511-512), trançados originaram ornamentos, notadamente os feitos a partir de folhas de palmeiras. Posteriormente, Ribeiro (1980: 5) salientou que a relevância dos trançados ultrapassa sua utilidade prática e beleza, inspirando "toda uma arte decorativa que se fundamenta nas linhas geométricas esboçadas no ato de entretecer". Embora tais entendimentos possam evocar uma visão evolucionista, a origem simultânea de grafismos e trançados consta no próprio pensamento ameríndio.

Além do supracitado caso Mbyá-Guarani (Baptista da Silva, 2001), a origem de desenhos e trançados se encontra entre vários povos. Para muitos dos falantes de línguas Karib, como Waiwai, Hixkaryana, Katxuyana, Kalinã, Carib, Carijona e Wayana, assim com os Waujá, falantes de língua Arawak, tal origem vincula-se ao tema da serpente sobrenatural (Barcelos-Neto 2011; Frikel 1970; Velthem 1998; Yde 1965). No caso Ye'kuana, os desenhos aplicados em trançados foram copiados das pinturas faciais do macaco-aranha-xamã (Guss 1994). Para os Baré trançados e padrões decorativos foram retirados do redemoinho da cabeça de seres míticos (Velthem \& Robert 2012).

Entre os Desana, os desenhos ora se originaram a partir da produção de cestos usados para trocas de mulheres, ora se originaram por um evento no qual os homens ficaram sob o efeito de alucinógeno e enxergaram o padrão trançado hexagonal (Reichel-Dolmatoff 1985).

O hexágono, além de ser uma figura que costuma ser vista em estágios iniciais do uso de alucinógenos, é para os Desana o padrão colmeia de abelha (Reichel-Dolmatoff 1985: 19).

Caracterizados pela simultaneidade na manufatura, em que trançar com ambas as mãos produz sincronicamente cesto e padrão gráfico, os trançados estão mais próximos das tecnologias demiúrgicas para os Wayana (Velthem 2009: 226). Dentre todos os suportes que podem receber grafismos, os trançados de arumã são os que recebem maior variedade de repertórios gráficos (Velthem 2007).

Já que atuam em muitas esferas da vida indígena, os trançados se relacionam com outras categorias artefatuais mais valorizadas pela Arqueologia, como a cerâmica, conforme atestam muitas marcas de trançados em bases de potes, além de auxílio na cozinha, em atividades de peneirar, coar, entre outras. Eles podem até se relacionar com grafismos rupestres. Considerando as concepções míticas e comparando os grafismos presentes em vários suportes, como rupestres, ralados, malocas, bancos, maracás, porta-charutos, cerâmicas e corpos humanos, Ribeiro (1980: 413) concluiu que:

os padrões geométricos presentes na arte alto rionegrina se inspiram em desenhos derivados dos trançados, uma vez que tamanha semelhança não pode ser explicada por fatores meramente acidentais. 
A autora informou que diversas gravuras rupestres são identificadas pelos nativos como balaios e peneiras, assinalando que algumas cachoeiras levam nomes de padrões derivados dos trançados e, ainda, que os cesteiros passam as mãos nas inscrições rupestres de trançados para aperfeiçoarem suas habilidades (Ribeiro 1980: 379). Para os Desana, os petróglifos circulares e concêntricos são bandejas trançadas de caráter mnemônico (Reichel-Dolmatoff 1985: 20).

Independentemente se os grafismos ameríndios são originários ou não dos trançados, o exposto realça a importância de considerar esta categoria artefatual também nos estudos acerca da relação entre os humanos e a materialidade em seus amplos aspectos visuais. Uma contribuição valiosa nesse sentido seria comparar os intrínsecos padrões dos trançados com os demais grafismos dispostos em diversos vestígios arqueológicos, uma vez que trançados ainda persistem na vida ameríndia, possuindo papel proeminente em seu pensamento.

Grafismos são imanentes aos trançados e ambos surgem e se desfazem concomitantemente. Monocrômicos na maioria dos casos, os grafismos estão presentes não só nas partes mais visíveis dos corpos trançados, mas se encontram discretamente nas partidas e arremates. Identificá-los nem sempre é fácil e a imersão etnográfica é uma boa forma de aprender a vê-los. Trançar é fazer grafismos e os padrões ornamentais marcam identidades, possuem camadas de significados, transmitem princípios ontológicos e agem sobre quem os utiliza (Ribeiro 1980, 1989; Vidal 1992; Velthem, 2001, 2003, 2007). Se grafismos adicionados à superfície de artefatos de madeira, cerâmica, entre outros, podem vir a esmaecer com o uso, eles jamais escapam das tramas e urdiduras de um trançado qualquer, a menos que o próprio trançado se desfaça. Portanto, estudar trançados-grafismos é considerar plenamente a noção de estilo tecnológico (Lemonnier 1992; Letchman 1977; Reedy \& Reedy, 1994), evitando pensar o estilo enquanto atributo puramente estético ao articular as escolhas sobre materiais e técnicas produtivas com a aparência e função do que é produzido.

\section{O projeto "tramas da tecnologia"}

No intuito de contribuir para a visibilidade dos trançados na Arqueologia, iniciou-se o projeto "Tramas da Tecnologia: etnoarqueologia e variabilidade dos trançados Waiwai". Como o estudo está em andamento, este artigo apresentará apenas algumas observações pontuais.

Desenvolvida no norte do Pará, a pesquisa entre os povos do rio Mapuera, genericamente conhecidos como Waiwai, aborda as técnicas de produção e a variabilidade dos trançados, englobando as relações sociais e os significados culturais que os permeiam, bem como está compreendendo o modo pelo qual estes povos diferenciam e classificam essa ampla categoria artefatual. Nesse sentido, coleções etnográficas têm sido essenciais no diálogo e na compreensão de continuidades e mudanças ao longo dos últimos cem anos.

Em qualquer aldeia do rio Mapuera pode-se observar constantemente pessoas se relacionando com trançados. Cargueiros auxiliam no transporte e armazenamento de alimentos e lenha (Fig. 2A, Fig. 2B); pequenos abanos são dados às crianças para que elas brinquem e aprendam sobre eles (Fig. 2C); diferentes gerações de artesãos podem ser vistas trançando ao lado de objetos industrializados (Fig. 2E); diversos tipos de bandejas servem alimentos (Fig. 3A, Fig. 3B), auxiliam no preparo do beiju (Fig. 3F) e podem recolher a massa de mandioca processada em um ralo de madeira, cujos dentes de pedras lascadas (Fig. 3C) poderiam estar antes guardados num trançado (Fig. 3D).

Amplamente distribuídos, os trançados estão emaranhados com outras tecnologias, como a da caça e as técnicas da construção dos corpos humanos, por exemplo. Ao guardar pontas de flechas com curare, um estojo (Fig. 4A, Fig. 4B) conserva concomitantemente a sabedoria especializada de caça e narrativas míticas sobre o próprio evento que originou os trançados e seus intrínsecos grafismos. Em linhas gerais, esse veneno foi outrora usado para matar a serpente sobrenatural uruperi e a partir de sua pele foi possível aprender ao mesmo tempo trançar e fazer grafismos. 


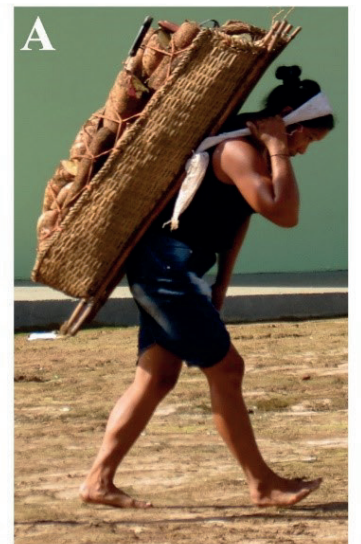

Cesto-cargueiro carregado de mandioca

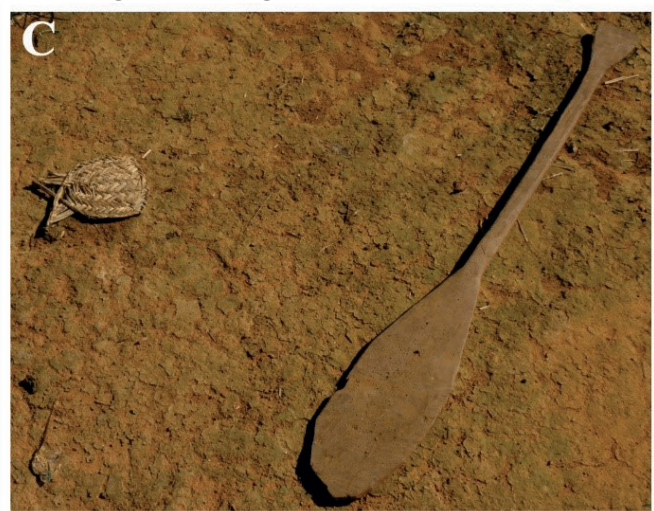

Miniatura de abano para crianças repousando ao lado de um remo de madeira

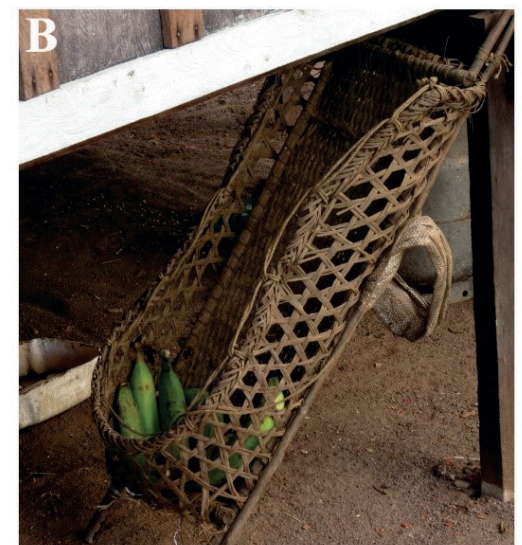

Cesto-cargueiro armazenando banana

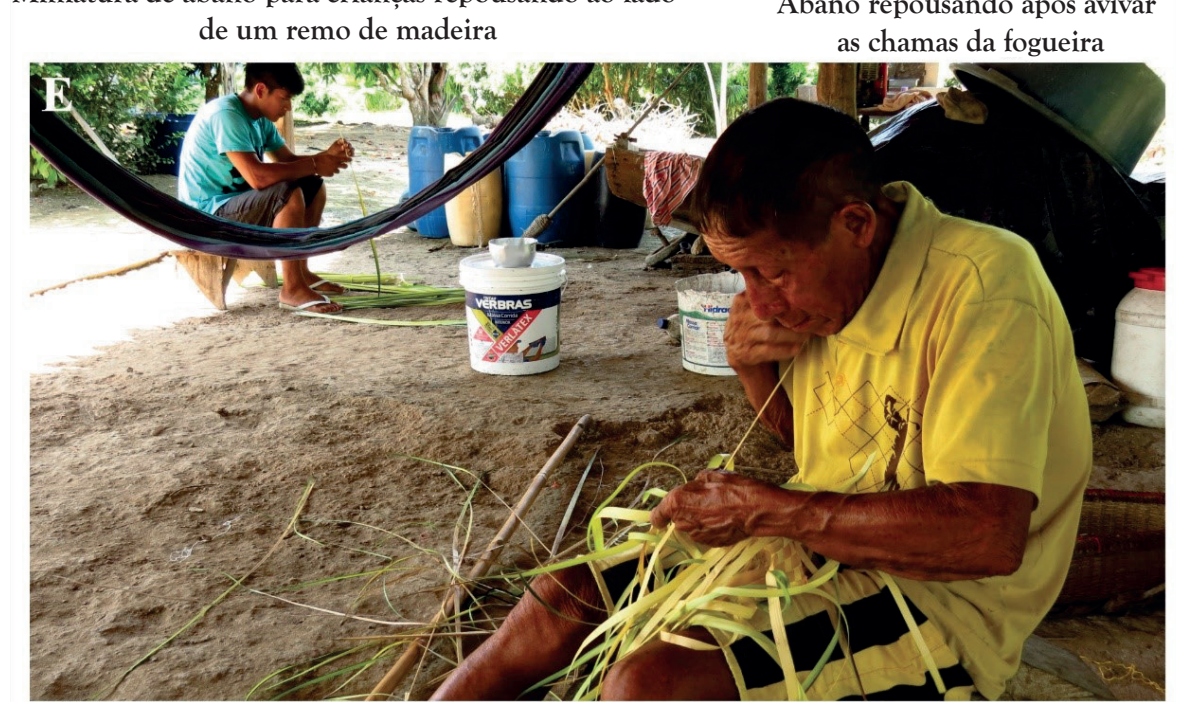

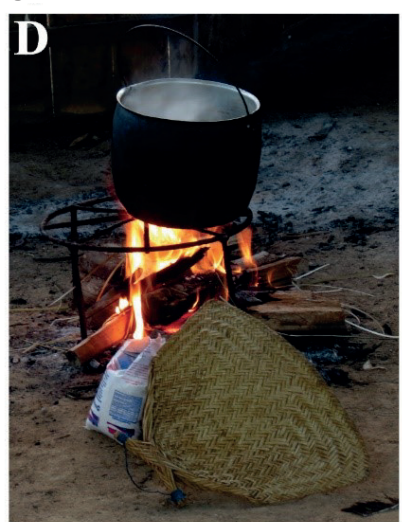

Abano repousando após avivar as chamas da fogueira

No primeiro plano, o avô Tikti trança uma caixa enquanto seu neto Kleberson, ao fundo, prepara as folhas novas de tucumã para trançar um abano

Fig. 2. Trançados em ação, em repouso e em construção.

Fonte: Fotos do Autor. 


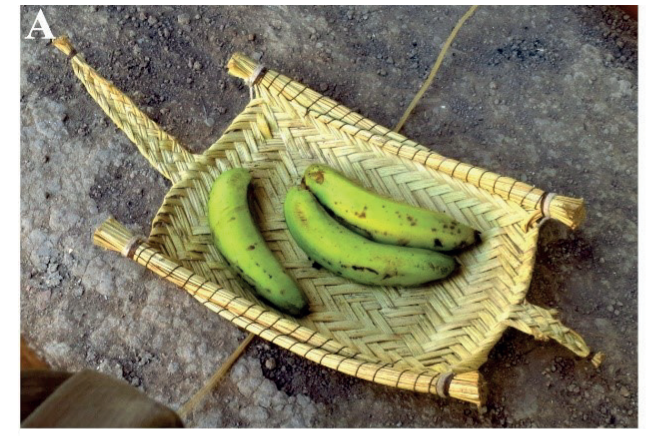

Bandeja em forma de tatu servindo bananas

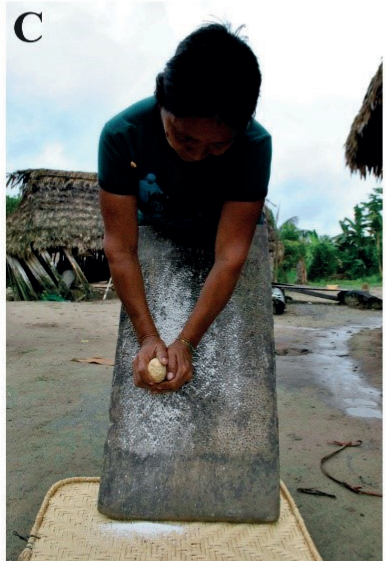

Bandeja recolhendo a massa da

mandioca ralada

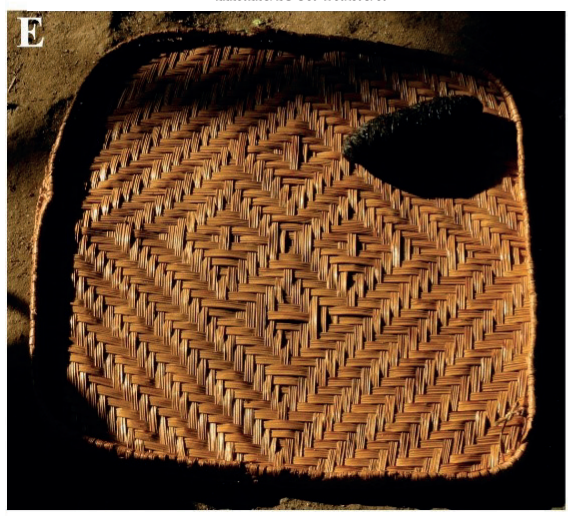

Pequena bandeja com "padrão olhos do macaco-prego" (quadrados no centro)

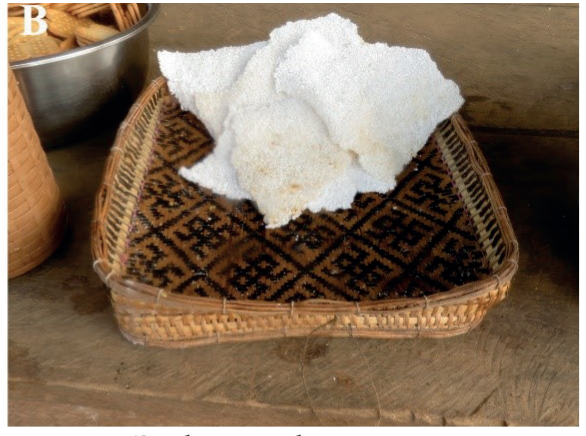

Bandeja servindo tapioca

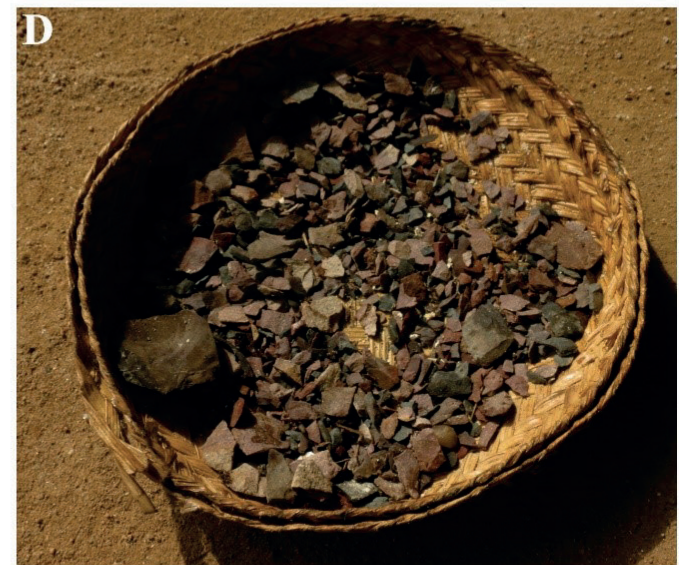

Pequena bandeja guardando pedras lascadas para posterior uso como dente de ralor

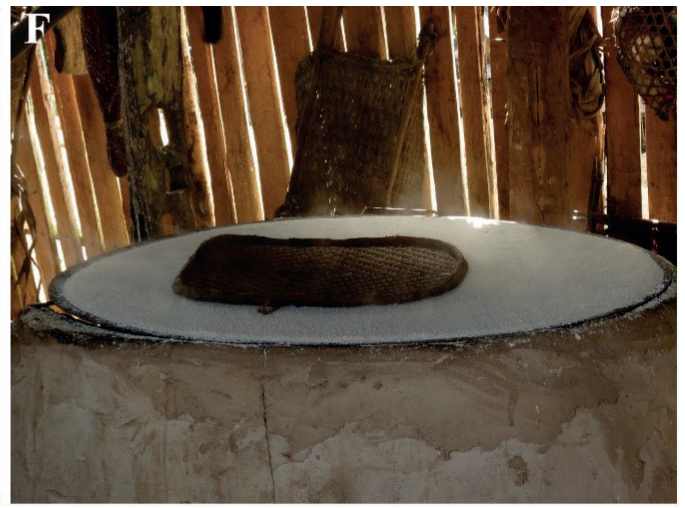

Cuure erematantopo usado para preparar o beiju

Fig. 3. Diferentes bandejas e seus usos.

Fonte: Fig. 3C: foto de Camila Jácome. Fig. 3A, 3B, 3D, 3E, 3F: fotos do Autor.

Há os cestos que reúnem miudezas e diversos aparatos para enfeite, assim como existem suportes trançados que ostentam penas ao compor cocares (Fig. 4C) que, por sua vez, podem ser usados para marcar identidades em diversos eventos. Corpos humanos também se constroem por alimentos, e os trançados, um dos alicerces da culinária, são corpos que podem até ser manufaturados de modo a exibir padrões gráficos correspondentes a partes de corpos de outros seres, alguns que também servem 
de alimentos. Um exemplo é o padrão "olhos do macaco-prego" (meeku yewru) presente na face da bandeja que auxilia na produção do beiju (Fig. 3E). O macaco-prego é uma caça apreciada e certamente existem outros significados associados a ele.

Analogamente ao caso Wayana (Velthem 1998, 2003), observou-se entre os povos do Mapuera diferenças na denominação dos trançados conforme quem produz e quem utiliza. Tomando como exemplo a supracitada bandeja (Fig. 3E), um homem, produtor do
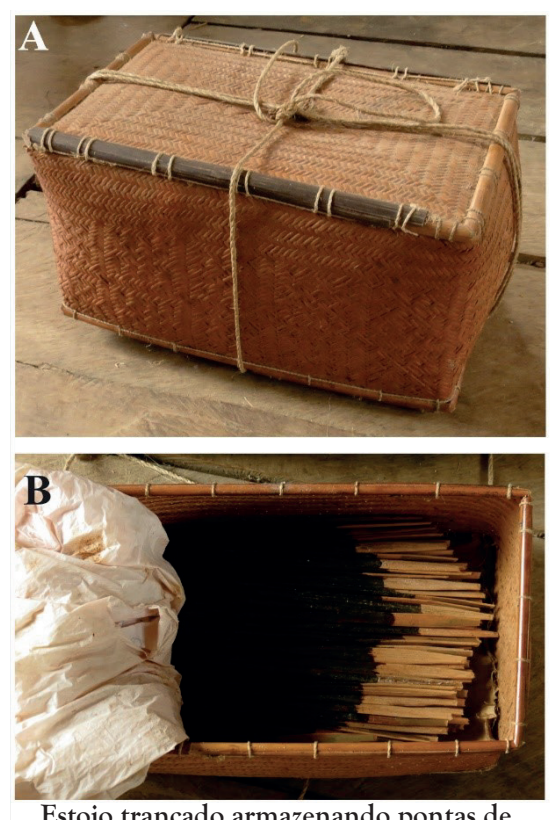

Estojo trançado armazenando pontas de flecha com curare cesto, pode se referenciar a ela por seu padrão gráfico: "meeku yewru" ("olhos do macaco-prego"). Já a mulher, que a utiliza, pode enfatizar sua função, chamando-a de "cuure erematantopo" ${ }^{\prime \prime}$ que em tradução livre seria "[bandeja] própria para assentar em cima do beiju”, já que para assá-lo adequadamente, é necessário o uso desse trançado. Porém, houve casos em que homens também chamaram essa bandeja de "cuure erematantopo", indicando que essa diferença de denominação não é extremamente rígida.

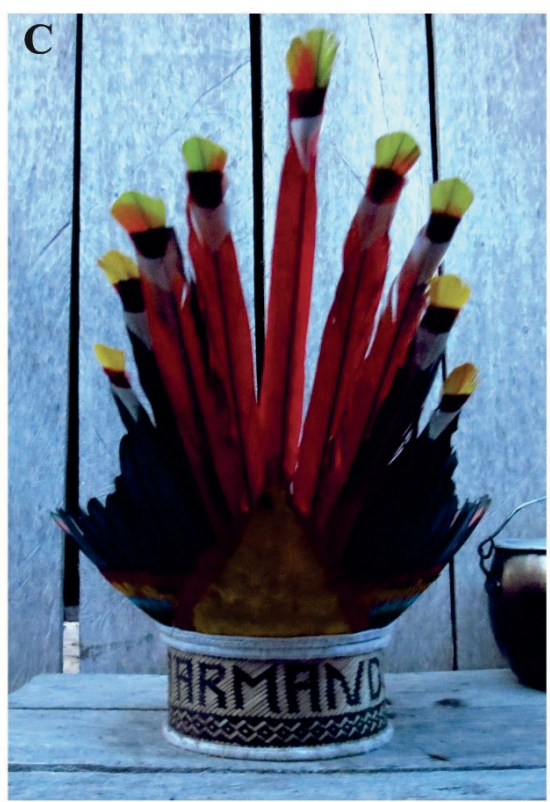

Cocar com suporte trançado apresentando o nome de seu dono "Armando"

Fig. 4. Trançados, caça e o corpo humano.

Fonte: Fotos do autor.

\section{Considerações finais}

Dada a grande quantidade de possibilidades técnicas e tipos de objetos possíveis de tecer, os trançados são um bom exemplo para estudos sobre variabilidade artefatual, tema peremptório em (etno)arqueologia. Sua variedade faz com que eles sejam vistos como culturalmente "sensíveis", apresentando alto potencial para estudos comparativos centrados na compreensão de idiossincrasias (Jolie \& Mcbrinn 2010). É possível

observar a individualidade dos artesãos e artesãs através de suas tramas (Newton 1981; Pryor \& Carr 1995; Taveira 1982; Silva 2011; Silvestre 2000; Wendrich 2012) e não há duas populações que trançam precisamente da mesma maneira (Adovasio \& Gunn 1977). Juntamente com os tecidos, trançados são tidos como indicadores-chave de estilos tecnológicos

4 Na escrita da língua waiwai, a letra "c" tem som de "tch", como em "tchau" e a letra "p" tem som de "f", como em "família". 
aprendidos, ao ponto de se afirmar que não se pode pensar em questões econômicas e de identidades sociais sem considerá-los (Stone 2011: 26). Eles são valiosos para abordar a materialidade sem ter como propósito único a produção de analogias para as inferências arqueológicas, sendo indispensáveis, portanto, para a compreensão holística das relações entre humanos e materiais. E não se trata apenas de mudarmos os materiais sobre os quais estudamos. É uma possibilidade de vislumbrar outros aspectos da vida num mundo material (Jolie \& Mcbrinn 2010).

Onipresentes e persistentes na vida ameríndia, os trançados se emaranham com outras tecnologias e ainda nos instigam a pensar além duma relação entre humanos e materiais, mas entre humanos e não humanos, no caso os vegetais com os quais se interage em diversas relações permeadas de significados e prescrições. Lembremos o mencionado caso Xikrin, no qual a tipoia tecida com buriti fornece boas qualidades a um recém-nascido (Silva 2000). Para os Warao, o arumã possui espírito e um mestre que transforma a mão do cesteiro (Wilbert 1975). Muitos dos vegetais trançados pelos Ye'kuana possuem donos e espíritos perigosos que precisam ser mediados pelos xamãs (Guss 1994).

A etnoarqueologia pode ajudar a ampliar o conhecimento sobre os trançados, por possibilitar a convivência com outros povos, os quais podem nos ensinar a ver além da aparência das coisas. Poderemos formular novas perguntas aos vestígios arqueológicos, ou estudar os trançados no próprio presente, contribuindo, de todo modo, para discussões teóricas e conceituais sobre materialidade e tecnologia. É uma forma de, paulatinamente, incluir os trançados no imaginário arqueológico e trazer, para primeiro plano, uma tecnologia até então invisibilizada, ainda que persistente. Ela é deveras complexa e passível de múltiplas leituras, permitindo-nos vislumbrar amplos aspectos da vida humana e não humana.

Enfim, os trançados são compostos por tramas que nos levam para outras tramas, sejam elas conceituais, de relações sociais, cosmológicas e ontológicas. Eles nos estimulam a pensar em múltiplos aspectos das tramas da tecnologia que são compostos por diferentes enredos, ou urdiduras, de significados. No estudo de caso aqui esboçado, tais urdiduras estão sendo entrançadas aos poucos.

\section{Agradecimentos}

Sou grato a todas as pessoas que se empenharam na organização da VI Semana Internacional de Arqueologia dos Discentes do MAE/USP. Agradeço ao Jaime, Cooni e Roque (owacarin komo), pela ajuda com a língua waiwai e por todas as conversas sobre nossas pesquisas. À Fabíola Silva agradeço a orientação e constante dicas de leituras, assim como sou grato ao Ruben Caixeta de Queiroz pela coorientação e Camila Jácome pelo incentivo e apoio. À Sarah Hissa e Meliam Gaspar pelas primeiras críticas ao texto. Agradeço ainda as lideranças indígenas, moradores e moradoras das aldeias do rio Mapuera por acolher a pesquisa, assim como ao IEPÉ pela oportunidade de colaboração no diagnóstico do PGTA. O Projeto "Tramas da Tecnologia: etnoarqueologia e variabilidade dos trançados Waiwai" conta com o financiamento da Fundação de Amparo à Pesquisa do Estado de São Paulo (FAPESP), através do Processo nº 2017/13343-4. 
RODRIGUES, I.M.M. Towards an ethnoarchaeology of Amerindian plaitworks. R. Museu Arq. Etn. 34: 87-110, 2020.

Abstract: Plaitworks are fundamental in basic activities among Amerindian peoples, such as transporting and food processing. They also occupy a prominent position in their ontology, expressing and turning active aesthetic precepts and worldviews. These objects offer excellent opportunities for studies on the multiple relationships between humans and the material world, such as artifact variability, technology, corporeality, as well as others possibilities. Even so, they are understudied by Archaeology and Ethnoarchaeology. This small research investment is perhaps due to the low potential for preservation of these materials in the archaeological record, which leads to a lack of knowledge and dissemination on the different possibilities of plaitworks studies, both from empirical and theoretical points of view. Plaitworks are perishable, however, they persist in Amerindians' life, entangled with others technologies. If Archaeology serves to understand the relationship of Amerindian peoples and the material world holistically, then it is also necessary to include these artifacts in the Archaeology agenda. This paper, therefore, aims to highlight the research potential that plaitworks provide for ethnoarchaeological approach. Some inquiry possibilities are indicated by previous studies, and through my ongoing doctoral research.

Keywords: Ethnoarchaeology; Plaitworks; Perishable technologies; Amerindian people; People of Mapuera River.

\section{Referências bibliográficas}

Adovasio, J. M. 1977. Basketry technology. Aldine Publishing Company, Chicago.

Adovasio, J.; Gunn, J. 1977. Style, basketry and basketmakers. In: Hill, J.; GUNN, J. (Orgs.).

The individual in prehistory: studies of variability in style prehistoric technologies. Academic Press, New York, 137-153.

Adovasio, J.; Illingworth, J.S. 2004. Prehistoric perishable fiber technology in the Upper Ohio Valley. In: Drooker, P.B. (Ed.). Perishable material culture in the Northeast. New York State Museum, New York, 19-30.

Adovasio, J. et al. 2014. Perishable fiber artifacts and paleoindians: new implications. North American Archaeologist 35: 331-352.
Al-Houdalieh, S. 2010. Survey of the historic core of Saffa Village. Ethnoarchaeology 2: 173-212.

Balfet, H. 1952. La vannerie: essai de classification. L'Anthropologie 56: 259-280.

Baptista da Silva, S. 2001. Etnoarqueologia dos Grafismos Kaingang: um modelo para a compreensão das sociedades proto-Jê meridionais. (Tese de Doutorado). Universidade de São Paulo, São Paulo.

Barcelos-Neto, A. 2011. A serpente de corpo repleto de canções: um tema amazônico sobre a arte do trançado. Revista de Antropologia 54: 981-1012.

Biagetti, S.; Lugli, F. (Eds.). 2016. The intangible elements of culture in Ethnoarchaeological research. Springer International Publishing, Cham. 
Boas, F. 2014. Arte Primitiva. Vozes, Petrópolis.

Boomert, A. 1981. The trauma phase of Southern Suriname. Journal of the Walter Roth Museum of Archaeology and Anthropology 4: 105-152.

Brochado, J. P. 1977. Alimentação na floresta tropical. Universidade Federal do Rio Grande do Sul, Porto Alegre.

Casey, J.; Burruss, R. 2010. Social expectations and children's play places in Northern Ghana. Ethnoarchaeology 1: 49-72.

Castro, E. 1994. O cesto kaipó dos Krahó: uma abordagem visual. Dissertação de mestrado. Universidade de São Paulo, São Paulo.

Clastres, P. 1990. A sociedade contra o Estado. Francisco Alves, Rio de Janeiro.

Costa, R. L. 2016. Palha e tala: estudo da tecnologia do trançado entre grupos pré-históricos brasileiros. Tese de doutorado. Universidade Federal do Rio de Janeiro, Rio de Janeiro.

Costa, R. L.; Lima, T. A. 2016. A arte e técnica de trançar na Pré-história de Pernambuco: a cestaria dos sítios Alcobaça e Furna do Estrago. Clio Arqueológica 31: 102-152.

Costa, R. L.; Moraes, F. A. A. 2019. A produção cesteira e de cordoarias na pré-história do Cariri paraibano. Revista de Arqueologia 32: 207-221.

Cunningham, J. J. 2009. Ethnoarchaeology beyond correlates. Ethnoarchaeology 1: 115-136.

Daniel, H.; Beldados, A. 2018. Ethnoarchaeological study of Noog (Guizotia abyssinica (L. f.) Cass., Compositae) in Ethiopia. Ethnoarchaeology 10: 16-33.

David, N.; Kramer, C. 2001. Ethnoarchaeology in action. Cambridge University Press, Cambridge.

Dutra, L.; Okumura, M. 2018. Cestos enterrados no vale do Peruaçu: classificação e utilização dos artefatos têxteis e trançados dos sítios sob abrigo do norte de Minas Gerais. Revista de Arqueologia 31: 131-50.

Evans, C.; Meggers, B. 1960. Archaeological investigations in British Guiana. Bureau of American Ethnology Bulletin 177: 1-418.

Frikel, P. 1970. Os Kaxúyana: notas etno-históricas. Museu Paraense Emílio Goeldi, Belém.

Frikel, P. 1973. Os Tiriyó: seu sistema adaptativo. Völkerkundliche Abhandlungen des Niedersächsischen Landesmuseums Hannover 5.

Fuerst, R. 1970. Une civilisation du Palmier. Zeithschrift Ethnologie 95: 114-122.

Gallay, A. 2016. A plea for general Anthopology. In: Biagetti, S.; Lugli, F. (Eds.). The intangible elements of culture in ethnoarchaeological research. Springer International Publishing AG, Cham, 3-35.

Gillin, J. 1948. Tribes of the Guianas and the left Amazon tributaries. In: Steward, J. (Ed.). Handbook of South American Indians. Smithsonian Institution, Washington, 3, 799-860.

González-Ruibal, A. 2003. La experiencia del otro: una introducción a la etnoarqueología. Akal, Madri.

González-Ruibal, A. 2008. De la etnoarqueología a la arqueología del presente. In: Bonet, J.S.; Azkárraga, J.M.; Rosado, H.B. (Coords.). Mundos Tribales: uma visión etnoarqueológica. Museu de Prehistoria de Valencia, Valencia 16-27.

González-Ruibal, A. 2016. Ethnoarchaeology or simply archaeology? World Archaeology 8: 687-692.

González-Ruibal, A.; Hernando, A.; Politis, G. 2013. Ontologia da pessoa e cultura material: manufatura de flechas entre os caçadores-coletores Awá. In: Hernando, A.; Coelho, E.M.B. (Orgs.). Estudos sobre os Awá: caçadores-coletores em transição. Ed. EDUFMA/IWGIA, São Luís 91-130.

Gosselain, O.P. 2016. To hell with ethnoarchaeology. Archaeological Dialogues 23: 215-228. 
Guss, D.M. 1994. Tejer y cantar. Monte Ávila Editores Latinoamericana, Caracas.

Hames, R.B.; Hames, I.L. 1976. Ye'kwana Basketry: its cultural context. Antropológica 44: 3-58.

Hamilakis, Y. 2011. Archaeological ethnography: a multitemporal meeting ground for archaeology and anthropology. Annual Review of Anthropology 40: 399-414.

Hilbert, P.P. 1955. A cerâmica arqueológica da região de Oriximiná. Museu Paraense Emílio Goeldi: Belém.

Hirshman, A.; Stawski, C.J. 2013. Distribution, transportation, and the persistence of household ceramic production in the Tarascan State. Ethnoarchaeology 5: 1-23.

Ingold, T. 2001. Beyond art and technology: the anthropology of skill. In: Schiffer, M. B. (Org.). Anthropological perspectives on technology. University of New Mexico Press, New Mexico, 17-31.

Jolie, E.; Mcbrinn, M. E. 2010. Retrieving the perishable past: experimentation in fiber artifact studies. In: Ferguson, J. R. (Ed.). Designing experimental research in archaeology: examining technology through production and use. University Press of Colorado, Boulder, 153-193.

Jolie, E. et al. 2011. Cordage, textiles, and the Late Pleistocene peopling of the Andes. Current Anthropology 52: 285-296.

Jones, S. 2009. Food and gender in Fiji: ethnoarchaeological explorations. Lexington Books, New York.

Jones, S. et al. 2012. Talking trash. Ethnoarchaeology 4: $147-184$

Kindell, G. 1971. Kaingáng basketry. In: Gudschinsky, S.C. (Ed.), Estudos sobre línguas e culturas indígenas: trabalhos linguísticos realizados no Brasil. Instituto Linguístico de Verão, Brasília, 143-173.
Lagrou, E. 2009. Arte indígena no Brasil: agência, alteridade e relação. C/ Arte, Belo Horizonte.

Lane, P. 2015. Peripheral vision: reflections on the death and rebirth of ethnoarchaeology. In: Crook, R.; Edwards, K.; Hughes, C. (Eds.). Breaking barriers. Proceedings of the $47^{\text {th }}$ Annual Chacmool Archaeological Conference. November 7-9, 2014. The University of Calgary, Calgary, 19-34.

Lechtman, H. 1977. Style in technology - some early thoughts. In: Lechtman, H.; Merrill, R.S. (Eds.). Material culture: styles, organization, and dynamics of technology. West Publishing, St Paul, 3-20.

Lehmann, J. 1907. Systematik und Geographische Verbreitung der Geflechtsarten. Abhandlungen und Berichte des Koniglich Zoologischen und Anthropologisch-Ethnographischen Museums zu Dresden XI: 3.

Lemonnier, P. 1992. Elements for an Anthropology of technology. University of Michigan, Michigan.

Leroi-Gourhan, A. 1971. Evolução e técnicas: I- O Homem e a Matéria. Edições 70, Lisboa.

Lévi-Strauss, C. 1995. Mirar, escuchar, ler. Ediciones Siruela, Madri.

Lévi-Strauss, C. 1986. O uso das plantas silvestres da América do Sul tropical. In: Ribeiro, B. (Coord.). Suma Etnológica Brasileira. Vozes, Petrópolis, 1, 29-46.

Lévi-Strauss, C. 2004. O cru e o cozido. Cosac \& Naify, São Paulo.

Lyons, D. 2009. How I built my house. Ethnoarchaeology 2: 137-162.

Lyons, D.; Casey, J. 2016. It's a material world: the critical and on-going value of ethnoarchaeology in understanding variation, change and materiality. World Archaeology 48: 609-627. 
Manson, O.T. 1904. Indian basketry. Studies in a textile art without machinery. Doubleday, Page \& Company, New York, 1.

Marciniak, A.; Yalman, N. (Eds.). 2013. Contesting ethnoarchaeologies. Traditions, Theories, Prospectus. Springer, New York.

Mauss, M. 2003. As Técnicas do corpo. Sociologia e Antropologia. Cosac \& Naify, São Paulo, 399-422.

Mentz Ribeiro, P. A. 2000. Os horticultores de Roraima. In: Tenório, M.C. (Org.). Pré-história da Terra Brasilis. Editora UFRJ, Rio de Janeiro, 339-344.

Micou, C.P.; Ancibor, E. 1994. Manufactura cesteira em sítios arqueológicos de Antofagasta de la Sierra, Catamarca (República Argentina). Journal de la Société des Américanistes, 80: 207-216.

Newton, D. 1981. The individual in ethnographic collections. Annals of the New York academy of sciences 376: 267-287.

Nimuendajú, C. 2004. In pursuit of a past Amazon: archaeological researches in the Brazilian Guyana and in the Amazon region. Värlskulturmurseet, Göteborg.

Ochsenschlager, E.L. 2004. Iraq's Marsh Arabs in the Garden of Eden. University of Pennsylvania, Philadelphia.

O’neale, L. 1986. Cestaria. In: Ribeiro, B. (Coord.). Suma etnológica brasileira. Vozes, Petrópolis, 2, 323-349.

Piqué, R. et al. 2016. Not just fuel: food and technology from trees and shrubs in Falia, Saloum Delta (Senegal). In: Biagetti, S.; Lugli, F. (Eds.) The intangible elements of culture in ethnoarchaeological research. Springer International Publishing, Cham, 217-230.

Politis, G. 2007. Nukak: Ethnoarchaeology of an Amazonian People. Left Coast Press, Walnut Creek.

Porro, A. 1992. História indígena do alto e médio Amazonas: séculos XVI a XVIII. In: Cunha,
M.C. (Org.). História dos índios no Brasil. Cia das Letras, São Paulo, 175-196.

Pryor, J.; Carr, C. 1995. Basketry of Northern California Indians: interpreting style hierarchies. In: Carr, C.; Neitzel, J.E. (Eds.). Style, society, and person: archaeological and ethnological perspectives. Plenum Press, New York, 259-296.

Py-Daniel, A. R. 2010. O que o contexto funerário nos diz sobre populações passadas: o sítio Hatahara. In: Pereira, E.; Guapindaia, V. (Orgs.). Arqueologia amazônica. MPEG/IPHAN/SECULT, Belém, 2, 629-653.

Reedy, C.L.; Reedy, T.J. 1994. Relating visual and technological styles in Tibetan sculpture analysis. World Archaeology, 25: 304-320.

Reichel-Dolmatoff, G. 1985. Basketry as metaphor: arts and crafts of the Desana Indians of the Nortwest Amazon. Museum of Cultural History, Los Angeles.

Ribeiro, B. 1980. A civilização da palha: a arte do trançado dos índios do Brasil. Tese de Doutorado. Universidade de São Paulo, São Paulo.

Ribeiro, B. 1985. A arte do trançado dos índios do Brasil. Um estudo taxonômico. Museu Parense Emílio Goeldi, Belém; Instituto Nacional de Folclore, Rio de Janeiro.

Ribeiro, B. 1986a. A arte de trançar: dois macroestilos e dois modos de vida. In: Ribeiro, B. (Coord.). Suma etnológica brasileira. Vozes, Petrópolis, 2, 283-313.

Ribeiro, B. 1986b. Glossário dos trançados. In: Ribeiro, B. (Coord.). Suma etnológica brasileira. Vozes, Petrópolis, 2, 314-321.

Ribeiro, B. 1988. Dicionário do artesanato indígena. Itatiaia, Belo Horizonte; Universidade de São Paulo, São Paulo.

Ribeiro, B. 1989. Arte indígena, linguagem visual. Itatiaia, Belo Horizonte; Universidade de São Paulo, São Paulo. 
Ricardo, B. 2000. Arte Baniwa: cestaria de arumã. São Paulo, ISA, 2.

Rivière, P. 1992. Baskets and basketmakers of the Amazon. In: Mowat, L.; Morphy, H.; Dransart, P. (Eds.). Basketmakers: meaning and form in Native American baskets. University of Oxford, Oxford, 147-159.

Sahlins, M. 2007. A tristeza da doçura, ou a antropologia nativa da cosmologia ocidental. In: Sahlins, M. Cultura na prática. UFRJ, Rio de Janeiro, 561-617.

Schmidt, M. 1904. Ableitung Südamerikanischer Geflechtsmuster aus der Technik des Flechtens. Zeitschrift für Ethnologie 36: 490-512.

Seeger, A.; Matta, R.; Castro, E.V. 1979. A construção da pessoa nas sociedades indígenas brasileiras. Boletim do Museu Nacional 32: 2-19.

Silva, F. A. 2000. As tecnologias e seus significados: um estudo da cerâmica dos Asuriní do Xingu e da cestaria dos Kayapó-Xikrin sob uma perspectiva etnoarqueológica. Tese de Doutorado. Universidade de São Paulo, São Paulo.

Silva, F. A. 2009. A variabilidade dos trançados dos Asurini do Xingu: uma reflexão etnoarqueológica sobre função, estilo e frequência dos artefatos. Revista de Arqueologia 22: 17-34.

Silva, F. A. 2011. A tecnologia da cestaria entre os XikrinKayapó. In: Silva, F.A.; Gordon, C. (Orgs.). Xikrin: uma coleção etnográfica. Edusp, São Paulo, 173-190.

Silva, S. 2003. A vez dos cestos. Europress, Lisboa.

Silvestre, R. E. J. 1994. The ethnoarchaeology of Kalinga basketry: a preliminary investigation. In: Longacre, W.A.; Skibo, J.M. (Ed.). Kalinga Ethnoarchaeology: Expanding Archaeological Method and Theory. Smithsonian Institution Press, Washington, 199-224.

Silvestre, R. E. J. 2000. The ethnoarchaeology of Kalinga basketry: when men weave baskets and women make pots. Tese de Doutorado. University of Arizona, Tucson.

Smith, N. 2015. Palms and people in the Amazon. Springer, New York.

Stone, E. A. 2011. The role of ethnographic museum collections in understanding bone tool use. In: Baron, J.; Kufel-Diakowska, B. (Eds.. Written in bones: studies on technological and social contexts of past faunal skeletal remains. Uniwersytet Wrocławski, Wrocław, 25-37.

Taveira, E. L. M. 2005. Análise do material de fibras e palhas vegetais trabalhadas. In: Vialou, A.V. (Org.). Pré-história do Mato Grosso. Edusp, São Paulo, 1, 215-239.

Taveira, E. L. M. 1982. Etnografia da cesta Karajá. UFG, Goiânia.

Velthem, L. H. V. 1992. Arte indígena: referentes sociais e cosmológicos. In: Grupioni, L. D. B. (Org.). Índios no Brasil. Ministério da Educação e do Desporto, Brasília, 83-92.

Velthem, L. H. V. 1998. A pele de Tuluperê. Museu Paraense Emilio Goeldi, Belém.

Velthem, L. H. V. 2001. The woven universe: Carib basketry. In: McEwan, C.; Barreto, C.; Neves, E. (Eds.). Unknown Amazon: culture in nature in Ancient Brazil. The British Museum Press, London, 198-213.

Velthem, L. H. V. 2003.O Belo é a Fera. A estética da produção e da predação entre os Wayana. Lisboa, Museu Nacional de Etnologia/Assírio e Alvim.

Velthem, L. H. V. 2007. Trançados indígenas norte amazônicos: fazer, adornar, usar. Revista de Estudos e Pesquisas 4: 117-146.

Velthem, L. H. V. 2009. Mulheres de cera, argila e arumã: princípios criativos e fabricação material entre os Wayana. Mana 15: 213-236. 
Velthem, L.H.V.; Robert, P. 2012. Watura e Kak: Cestos Cargueiros Ameríndios. Revista AntHropológicas 23: 7-27.

Vidal, L. (Org.). 1992. Grafismo indígena: estudos de antropologia estética. Studio Nobel, São Paulo; Editora da Universidade de São Paulo, São Paulo; FAPESP, São Paulo.

Viveiros de Castro, E. 2002. A Inconstância da alma selvagem e outros ensaios de antropologia. Cosac \& Naify, São Paulo, 345-399.

Viveiros de Castro, E. 2015. Metafísicas canibais. Cosac \& Naify, São Paulo.

Wagley, C.; Galvão, E. 1961. Os índios Tenetehara. Serviço de documentação, Ministério da Educação e Cultura, Rio de Janeiro.

Weber, R.L. 1986. Emmons's notes on field museum's collection of Nortwest Coast basketry: edited with an Ethnoarchaeological Analysis. Field Museum of Natural History, Chicago.
Wendrich, W. 2012. The world according to basketry: an ethno-archaeological interpretation of basketry production in Egypt. Cotsen Institute Press, Los Angeles.

Wendrich, W. 2013. The Relevance of Ethnoarchaeology: an Egyptian perspective. In: Marciniak, A.; Yalman, N. (Eds.). Contesting ethnoarchaeologies. Traditions, Theories, Prospectus. Springer, New York, 191-209.

Wilbert, J. 1975. Warao basketry: form and function. G. Rice \& Sons, Los Angeles.

Wilmsen, E.N. et al. 2016. Moijabana Rocks-Pilikwe pots: the acceleration of clay formation by potters employing simple mechanical means. Ethnoarchaeology 8: 137-157.

Wissler, C. 1970. Los indios de los Estados Unidos de América. Paidós, Buenos Aires.

Yde, J. 1965. Material culture of the Waiwái. National Museum of Denmark, Copenhagen. 